which does not emphasize, or even over-emphasize, this correlation. Is it reasonable to ask a student to memorize the differences between the cell types of tho adenohypophysis without mentioning that they secrete hormones and without explaining that the staining differences are due to the chemical nature of those hormones? Why omit reference to the function of RNA in nerve cells, plasma cells and hæmocytoblasts ? Surely nothing can bo duller to teach or to learn than the differences in structure of different parts of the nephron; but, taken in conjunction with the structure shown by electron microseope and with modern theorios of urine formation, the same differences are understandable, fascinating and easy to remember.

F. H. LEACH

\section{Seals of the World}

By Judith E. King. Pp. 154. (London: British Museum (Natural History), 1964.) $11 s$.

MISS KING has performed a most useful task in bringing together in succinct form so much information on the Pinnipedes. This group has sustained more attack from man than any other ordor of mammals, and only in this contury has any attempt been made to preserve this valuable animal resource. Work carried out by American, British, Canadian, French, Australian and Russian biologists has gradually built up a body of knowledge which, within the foreseeablo future, will allow a policy of management to be applied to most of the threatened species (see also Nature, 204, 522; 1964).

In the first half Miss King gives an account of the thirty-two species, including their classification and interrolationships and their distribution both past and present. Such features as the breeding biology, food, social behaviour, longevity and seasonal movements aro included where they are known, and estimates of the world population are also given where possible. This part forms a most valuable synthesis of our present knowledge.

In the second half, aspects common to tho group as a whole are dealt with. There aro chapters on: distribution and ocean currents; body form and locomotion; skin, fur, moult and temperature control; skull and skoleton; dentition and age determination; alimentary, respiratory, vascular, nervous and reproductive systoms; senses; and diving abilities. Two final chapters on the scarce fossil history and on the parasites recorded complete a really comprehensive survey. I applaud the inclusion of the reasons (origins) of the scientific names which brings to life for the layman what is often regarded as an arid field of zoology.

The maps and line drawings are excellent; clear and unambiguous. It is pleasant to find all tho places mentioned in the text shown on the maps. The photographs of species are good but could perhaps have boen more plentiful, although this would have raised the very moderate cost. The literature list might also have been longer, but it includes enough to lead to the rest and that is the main object in such a work as this, which should certainly be on the shelves of the libraries of all departments of zoology as well as those of the public libraries

\section{H. R. HEWER}

\section{Comptes rendus du 3ème Congrès d'EUCARPIA}

(Association Européenne pour l'Amélioration des Plantes), Paris, 21-28 Maj, 1962. (Third Congress of the European Association for Research on Plant Breeding.) Pp. 336. (Paris: Institut National de la Recherche Agronomiquo, 1964.) 37 francs.

7 HE Association Européenne pour l'Amélioration des Plantes provides annually one of the few opportunities for European plant breeders to assemble and to exchange ideas and experiences. This report of its third congress in Paris in 1964 is a full description of the proceedings of the meeting including the complete texts, with tables and illustrations, of the papers, twenty-one in all, delivered there.

In the first of eight sessions, R. Mayer described, in a historical fashion, the progress and organization of plant breeding in France. The themes of six following sessions were: dry matter production as an objective in plant breeding; disease resistance in plants; the fato of the mutated cell; induction of mutation and plant breeding; present views on the gene centre theory; and physiological aspects of quality. In a final session, $\mathrm{P}$. l'Héritior gave an account of present-day views on cytoplasmic inheritance. The final part of this report deals mainly with the activity of the Association and its various sections during preceding years.

This volume conveniently brings together somo of the recent findings and concepts of plant breeders and, as such, it will be of interest to a wide audience. In an otherwise very complete congress report, the only omission is the absence of records of discussions of the papers, the inclusion of which might have enabled the outsider to share more fully the benefit of the meeting of the Association.

\section{The Architecture of the Germplasm}

By Prof. Verne Grant. Pp. xv +236 . (New York and London: John Wiley and Sons, Inc., 1964.) $75 s$.

THE Architecture of the Germplasm is primarily 1 concerned with the way in which genos interact in development, and how their linkage or independence in inheritance is related to this. After an introduction. to Mendelian heredity there are useful discussions of multiple gene systems and of structural changes in chromosomes, particularly in relation to the evolution of close linkage of adaptive gene combinations. Examples have been chosen, where possible, from the flowering plants. In view of this, the decision of Prof. Grant largely to omit discussion of polyploidy in the interest of brevity is perhaps unfortunate. The book is addressed primarily to students in pure and applied genetics and to advanced biology students, and provides a clearly written account of a difficult subject.

A eriticism of the book is that it is not up to date. The literature appears to have been well surveyed up to about, the year 1957, but only superficially after that. This is particularly serious for the chapters concerned with the nature of the gene and with gene action. Progress in these fields has been so rapid in the past few years that an account based on what was known 6 or 8 years ago is of little value. Indeed, there are so many errors or misleading statements in these chapters ( 2 and 6 ) that readers would be well advised to omit them. Fortunately, such omission does not greatly mar the work as a whole, since the structure of the chromosome and the mechanisms of control of gene functioning in higher organisms are not yet understood in molecular terms. The recent advances on the boundary between biochemistry and genetics have therefore had little impact as yet on the ideas about gene: interaction which form the main theme of the book. For the same reason, these ideas cannot be regarded as more than interesting hypotheses until substantiated by a clearer understanding of the chromosome and how it is organized.

H. L. K. Whitehouse:

\section{Selected Works in Organic Chemistry}

By A. N. Nesmeyanov. Translated from the Russian by Dr. Avraham Birron and Z. S. Colo. Translation edited by David P. Gelfand. Pp. xvi+1172. (London and New York: Pergamon Press; Jerusalem: Academic: Press, 1963.) 200s, net.

$\mathrm{T}^{\mathrm{T}}$ is noted in the preface that the complete works of A. N. Nesmeyanov were published by the Academy' of Sciences, U.S.S.R., in 1959 , on the occasion of his sixtieth birthday -in the form of four volumes, embracing all his scientific papers which have appeared on various 